Check for updates

Cite this: RSC Adv., 2020, 10, 14618

Received 7th March 2020

Accepted 26th March 2020

DOI: $10.1039 / \mathrm{dOra02646h}$

rsc.li/rsc-advances

\title{
An approach to new chiral bicyclic imines and amines via Horner-Wadsworth-Emmons reaction $\dagger$
}

\author{
Jakub Iwanejko, ${ }^{a}$ Mateusz Sowiński, ${ }^{a}$ Elżbieta Wojaczyńska, (D) *a \\ Tomasz K. Olszewski (D) ${ }^{* a}$ and Marcin Górecki ${ }^{b}$
}

\begin{abstract}
New chiral bicyclic imines, enamines and amines were prepared via Horner-Wadsworth-Emmons reaction of hexahydroquinoxalin-2(1H)-one-derived phosphonate, as the source of a phosphonate carbanion, and a wide range of structurally diverse carbonyl substrates. The simplicity of the synthetic protocol, high selectivity, and broad substrate scope are the main advantages of the presented methodology.
\end{abstract}

\section{Introduction}

Chiral cyclic imines, particularly derivatives with five- and sixmembered rings, have arisen as an important class of nitrogen containing heterocycles, useful as synthetic intermediates of drugs, agrochemicals and pharmacologically relevant compounds. ${ }^{1}$ Among the latest examples, Zhang et al. described the preparation of an enantioenriched cyclic imine using Bosch's chiral lactam; the imine was applied for the construction of an important component in the total asymmetric syntheses of drugs, (-)-rhynchophylline and (+)-isorhynchophylline. $^{2} \mathrm{Wu}$ et al. reported a rhodium-catalyzed asymmetric 1,2-addition of arylboronic acids to six-membered 1,2,6-thiadiazinane 1,1-dioxide-type cyclic imines to afford highly optically active sulfamides (95-99\% ee). ${ }^{3}$ High diastereoselectivity and enantioselectivity was observed in a $[4+2]$ reaction between cyclic sulfonic imine and Boc-protected indole aldehyde yielding polycyclic pyridoindoles. ${ }^{4}$ Aza-Darzens reaction of cyclic $N$-sulfonylimines with $\alpha$-halogenated ketones provided a variety of tri- and tetrasubstituted aziridines, including benzofused heterocycles as well as spiro-structures in high yields, diastereo- and enantioselectivities (up to $>20: 1 \mathrm{dr}$ and $>99.9 \%$ ee). ${ }^{5}$ Among the known bicyclic heterocycles, the hexahydroquinoxaline-2 $(1 H)$-one derivatives represent an interesting new class of compounds with promising biological activity (Fig. 1), ${ }^{6}$ and can be considered as direct analogues of quinoxalin-2 $(1 H)$-ones, well known for their broad pharmacological properties e.g. inhibitors against Hepatitis C Virus (HCV) and potent candidates for antitumor therapeutics. ${ }^{7}$

${ }^{a}$ Faculty of Chemistry, Wroctaw University of Science and Technology, Wybrzeże Wyspiańskiego 27, 50-370 Wrocław, Poland. E-mail: elzbieta.wojaczynska@pwr.edu. pl; tomasz.olszewski@pwr.edu.pl

${ }^{b}$ Institute of Organic Chemistry, Polish Academy of Sciences, Kasprzaka St 44/52, 01224 Warsaw, Poland

$\dagger$ Electronic supplementary information (ESI) available. See DOI: 10.1039/d0ra02646h
Surprisingly in spite of interesting biological properties, preparation of hexahydroquinoxaline-2 $(1 H)$-one derivatives still remain problematic and there are only few synthetic strategies that allow access to those molecules (Scheme 1). Unfortunately, each of them suffers from some drawbacks and limitations. The classical approach is based on condensation of cyclohexane-1,2diamine with pyruvates (the Hinsberg reaction) (Scheme 1a). ${ }^{8 a, b}$ Unfortunately the chemical diversity using the latter methodology is limited by not always easy access to a wide range of pyruvates. Recently, a solid supported methodology was introduced by the group of Bräse using immobilized oxazolones in combination with difunctional nucleophiles and yielding heterocyclic products (Scheme 1b). ${ }^{8 c}$ This method, however,<smiles>CC(C)(C)c1cc(C2N[C@H]3CCCC[C@H]3NC2=O)c(O)c(C(C)(C)C)c1</smiles><smiles>[R]OP([R])(=O)C1N[C@H]2CCCC[C@H]2NC1=O</smiles>

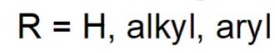<smiles>O=C(CC1=NC2CCCCC2NC1=O)NNC(=S)Nc1ccccc1</smiles>

antibacterial activity<smiles>O=C(CC1=NC2CCCCC2NC1=O)NN1C(=O)c2ccccc2C1=O</smiles>

Fig. 1 Examples of biologically active hexahydroquinoxaline-2(1H)one derivatives. 


\section{Previous works}

a) synthesis from ketoesters, Ref. $8 a, b$<smiles>[R]C(=O)C(=O)OCC</smiles>

b) solid state synthesis, Ref. $8 \mathrm{c}$<smiles>[R]C1=NC2(C)OC(=O)C([R])=NC2(C)OC1=O</smiles>

c) Pd-catalyzed sequential carbonylation / cyclization, Ref. 8d

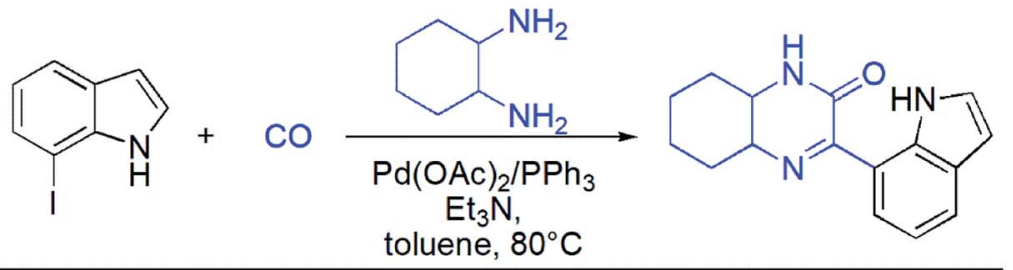

\section{This work}

d) Horner-Wadsworth-Emmons reaction<smiles>COP(=O)(OC)C1NC2CCCCC2NC1=O</smiles>

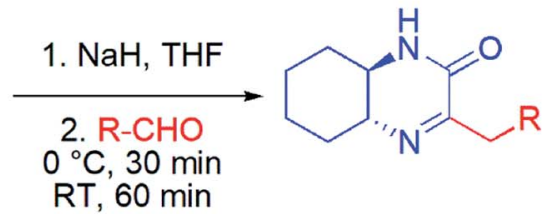

Scheme 1 Possible routes to hexahydroquinoxaline-2(1H)-one derivatives.

requires preparation in each case of new substituted oxazolone fragment and its subsequent introduction onto the resin which cannot be considered as straightforward process. Finally, palladium-catalyzed aminocarbonylation/cyclization synthetic strategy based on the use of carbon monoxide, cyclohexane-1,2diamine and iodoindoles was introduced (Scheme 1c). ${ }^{8 d}$ The need of using metal catalyst as well as narrow substrates scope are among the major limitations of this method.

In continuation of our interest in preparation of new heterocyclic compounds, ${ }^{9}$ we have recently reported on the synthesis of chiral hexahydroquinoxalin-2 $(1 H)$-one-derived phosphonates and identified them as intermediates for the asymmetric synthesis of hexahydroquinoxalin-2(1H)-one derivatives, especially bicyclic nitrogen-containing phosphonic acids but also imines and enamines. ${ }^{10}$ Importantly, the latter application, in contrast to the known approaches toward the preparation of those heterocycles, allows for an easy modification of the substituents around the carbon-nitrogen bond thus providing a selective and simple way to access those valuable building blocks. Herein, we present a detailed study on the scope and limitations of the application of
hexahydroquinoxalin-2(1H)-one-derived phosphonate, as the source of phosphonate carbanion, in the Horner-WadsworthEmmons reaction ${ }^{11}$ leading selectively to chiral heterocyclic imines, and amines as well as the use of the obtained compounds as building blocks in the preparation of other interesting bicyclic derivatives.

\section{Results and discussion}

The core intermediate in our approach, chiral hexahydroquinoxalin-2 $(1 H)$-one derived dimethyl phosphonate 2 , can be easily accessed, even on a multigram scale, via a simple twocomponent phospha-Mannich reaction between chiral imine 1 and dimethyl $H$-phosphonate (Table 1) ${ }^{10 a}$ Subsequent HornerWadsworth-Emmons (HWE) reaction performed in the presence of $\mathrm{NaH}$ in THF at $0{ }^{\circ} \mathrm{C}$ with a variety of aldehydes gave after total $2 \mathrm{~h}$ reaction time an access to structurally diverse products as tautomeric mixture of imine and enamine in which, in most cases, the imine form (3) predominated (Table 1). Composition of reaction mixtures in each case could be unambiguously established by ${ }^{1} \mathrm{H}$ NMR spectroscopy; measurements were 
Table 1 Results of HWE reaction using phosphonate 2 and various aldehydes

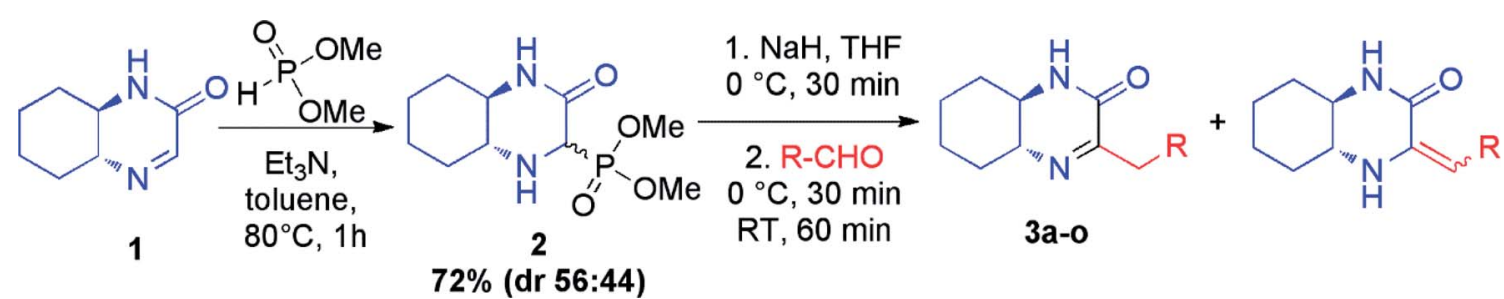

\begin{tabular}{|c|c|c|c|c|c|}
\hline Entry & $\mathrm{R}$ & Imine, $\%$ & Enamine, \% & Imine : enamine ratio & Imine product \\
\hline 1 & & 40 & 25 & $61: 39$ & $3 \mathbf{a}$ \\
\hline 2 & & $72^{a}$ & 3 & $96: 4$ & $3 \mathbf{b}$ \\
\hline 3 & & 50 & 31 & $62: 38$ & $3 c$ \\
\hline 4 & & $70^{a}$ & 24 & $75: 25$ & $3 d$ \\
\hline 5 & & $90^{a}$ & 4 & $96: 4$ & $3 e$ \\
\hline 6 & & 90 & 6 & $94: 6$ & $3 f$ \\
\hline 7 & & $96^{a}$ & 3 & $97: 3$ & $3 g$ \\
\hline 8 & & $83^{a}$ & 6 & $93: 7$ & $3 \mathbf{h}$ \\
\hline 9 & & $63^{a}$ & $<1$ & $99: 1$ & $3 \mathbf{i}$ \\
\hline 10 & & 33 & 22 & $60: 40$ & $3 \mathbf{j}$ \\
\hline 11 & & $79^{a}$ & 13 & $86: 14$ & $3 k$ \\
\hline 12 & & $68^{a}$ & 2 & $97: 3$ & 31 \\
\hline 13 & & $77^{a}$ & 1 & $99: 1$ & $3 m$ \\
\hline 14 & & $98^{a}$ & 2 & $98: 2$ & $3 n$ \\
\hline 15 & & $69^{a}$ & 3 & $96: 4$ & 30 \\
\hline 16 & & 33 & 48 & $41: 59$ & $3 \mathbf{p}$ \\
\hline
\end{tabular}




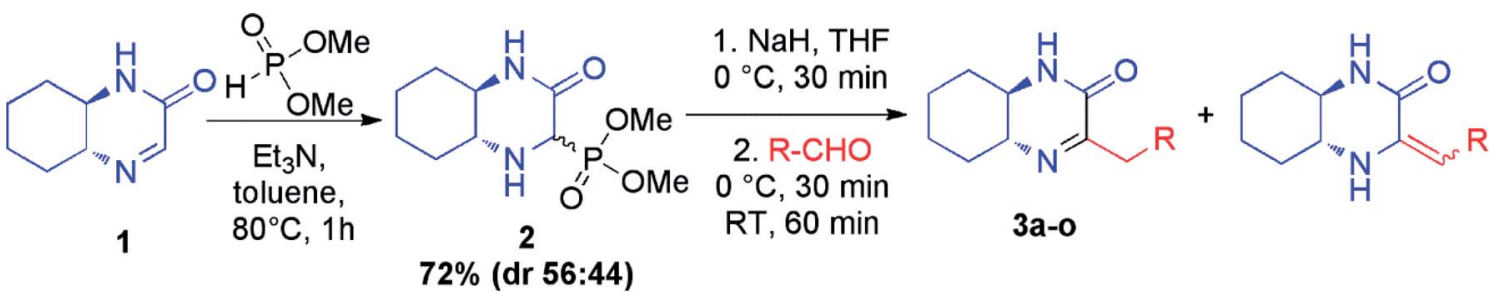

\begin{tabular}{llll}
\hline Entry & Imine, $\%$ & Enamine, \% & Imine : enamine ratio \\
${ }^{a}$ Pure imine isolated. & & 20 & 28 \\
\end{tabular}

performed after an extraction step on the crude products (see $\mathrm{ESI} \uparrow$ for details of experimental procedures).

When simple aliphatic aldehydes, acetaldehyde and butyraldehyde (Table 1, entry 1 and 3) were used, imine : enamine ratio of $c a .3: 2$ was found. The use of reactants with longer aliphatic chains significantly improved the selectivity of the reaction, leading predominantly to stable imines with a chemical yield of up to $90 \%$ (Table 1, entries 5 and 6).

Application of branched aldehydes provided stable substituted imines with high selectivity and yield (entries 7-9). Importantly, the desired imines were also obtained in case of cyclic aldehydes (entries 10-12). It was observed that the selectivity of the HWE reaction increased with ring enlargement. The derivative with the cyclopropyl substituent proved to be unstable (Table 1 entry 10). While the use of benzaldehyde led mainly to enamine in $98 \%$ yield, ${ }^{10 a}$ benzyl aldehyde afforded practically only imine product in $77 \%$ yield (Table 1 , entry 13 ). Similarly, high chemoselectivity was observed for other aldehydes bearing phenyl substituent at the alkyl chain (entries 14 and 15). Since citronellal and 3-phenylbutyraldehyde were used as racemic mixtures (entries 6 and 15), the resulting products bear an additional asymmetric center.

Lower selectivity was noted for aldehydes containing heteroatoms in their structure (Table 1, entries 16-18). The presence of sulfenyl group resulted in the reversed selectivity (imine : enamine ratio of $c a .2: 3$ ); also enantiomerically pure bicyclic aldehyde-2-azabicycloalkane derivative resulted in unstable unsaturated products, predominantly enamine (Table 1 , entry 18 ).

The crude mixtures were separated using column chromatography on silica gel. In general, we observed that the mixtures of tautomers containing above $90 \%$ of imine form were much easier separable. Newly synthesized and isolated imines were found to be stable both in air atmosphere as well as in common organic solvents. On the other hand, mixtures containing at least $20 \%$ of enamine were inseparable neither by column chromatography nor crystallization, and were unstable. We observed slow decomposition of products (in solutions) into complex mixtures, and isolation of pure imine or enamine was not possible. However, immediate reduction of such reaction mixture obtained from HWE reaction could be performed yielding chiral amines (vide infra) (Table 2).

Additionally, HWE reaction was also performed with ketones. The use of acetophenone in the reaction with phosphonate 2 led to a complex mixture of olefination products that was reduced in situ and from the four possible diastereomeric products (two new stereogenic centers were formed) the pure main diastereomer was isolated in $32 \%$ overall yield (Scheme 2). The configuration of this product was determined on the basis of correlations found in 2D ${ }^{1} \mathrm{H}$ NMR spectra (see ESI $\dagger$ for details). To our delight, a nearly quantitative reaction was observed with acetone. Unfortunately, imine and enamine were formed in practically equimolar amounts $(53: 47$ ratio) and we found them to be inseparable. Again, subsequent reduction of the crude reaction mixture was performed leading to mixture of chromatographically separable epimeric amines (71:29 diastereomeric ratio) from which both diastereomers was isolated in pure form with $63 \%$ and $25 \%$ overall yields (Scheme 2).

Subsequently, selected pure imines and also crude reaction mixtures containing imine and enamine were reduced with sodium borohydride (Table 2). An emphasis was put on the reduction of substrates bearing diverse substituents such as alkyl, cycloalkyl, alkylaryl groups as well as additional functional groups and heteroatoms. These reactions led to the 
Table 2 Reduction of imines and/or enamines with sodium borohydride

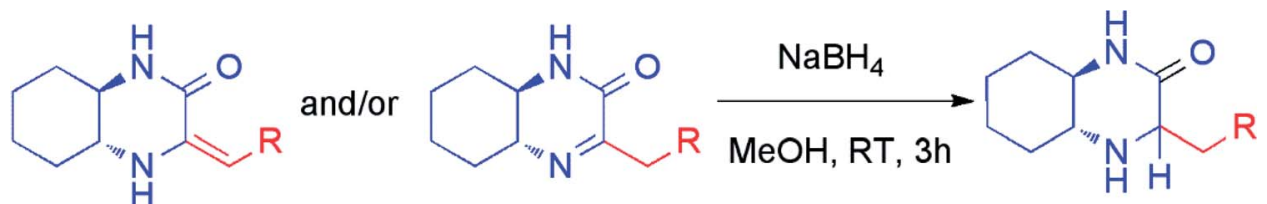

$5 \mathbf{a}-\mathbf{e}$

Entry

${ }^{a}$ A tautomeric imine/enamine mixture was used. ${ }^{b}$ In each case major diastereomer was isolated in pure form and absolute configuration was established (see ESI for details). ${ }^{c}$ The value of $\mathrm{dr}$ established based on the ${ }^{1} \mathrm{H}$ NMR of crude reaction product. ${ }^{d}$ Equimolar mixture of epimers.

formation of novel chiral amines with an additional stereogenic center. The resulting amines were purified by column chromatography and diastereomers were separated. Their configuration was established based on 2D NMR spectroscopy (Table 2). Reduction proceeded smoothly with a variable stereoselectivity which could be correlated with the steric hindrance exerted by the R substituent. This way, several enantiomerically pure amines 5a-e bearing three or more stereogenic centers were isolated with moderate to good diasteroselectivity. It is noteworthy that there was no external source of chirality used we have observed an induction of diastereoselectivity based on $(R, R)$-diaminocyclohexane fragment.

Finally, we decided to demonstrate the utility of the obtained hexahydroquinoxaline-2 $(1 H)$-one derivate imines as chiral building blocks in asymmetric preparation of other molecules. The imine 3i was selected as model substrate (Scheme 3). Addition of phosphorus nucleophiles to imine $3 \mathbf{i}$ provided corresponding aminophosphonic acid $\mathbf{6 e}$ and aminophosphonate $\mathbf{6 d}$ in high yield and excellent diastereoselectivity. In turn, reduction of the $\mathrm{C}=\mathrm{N}$ bond in $3 \mathbf{i}$ provided a mixture of epimeric amines 5a (ca. $4: 1$ ratio) and the major epimer of 5a could be separated by chromatography in $79 \%$ yield (Scheme 3 ). The latter was further subjected for reduction with lithium aluminum hydride to yield chiral cyclic diamine $6 f$ in $67 \%$ yield
(66\% overall yield from 5a, Scheme 3). In turn, to introduce sulfur functionality, cyclic imine $3 \mathbf{i}$ and amine $5 \mathbf{a}$ were treated with Lawesson's reagent (Scheme 3). Thioamide $\mathbf{6 b}$ containing imine function was obtained with $63 \%$ yield from imine $3 \mathbf{i}$ and also from amine 5a, albeit in lower yield (34\%). The reactivity of imine bond in this derivative was also checked. The aza-Pudovik reaction with dimethyl $H$-phosphonate appeared to proceed with a high diastereoselectivity comparable to $\mathbf{6 d}$, but with a low chemical efficiency (6a, $6 \%$ yield, not isolated). Finally, reduction of $\mathbf{6 b}$ with sodium borohydride yielded amine $\mathbf{6 c}$ bearing thiolactam fragment that was isolated in the form of two diastereomers that were isolated in pure form with $51 \%$ and $24 \%$ yield respectively (Scheme 3).

\section{Determination of the absolute configuration of $6 \mathrm{~d}$ and $6 \mathrm{e}$}

The assignment of absolute configuration (AC) of the main epimers $\mathbf{6 d}$ and $\mathbf{6 e}$ obtained in high diastereomeric excess was based on the comparison of their experimental and calculated electronic circular dichroism (ECD) spectra simulated using the time-dependent density functional theory (TDDFT). This combined methodology has illustrated its great efficiency in structural studies for many organic compounds having very different nature and origin. ${ }^{12}$ The ECD spectra of $\mathbf{6 d}$ and $\mathbf{6 e}$ were measured in acetonitrile. They exhibit very similar profile which 


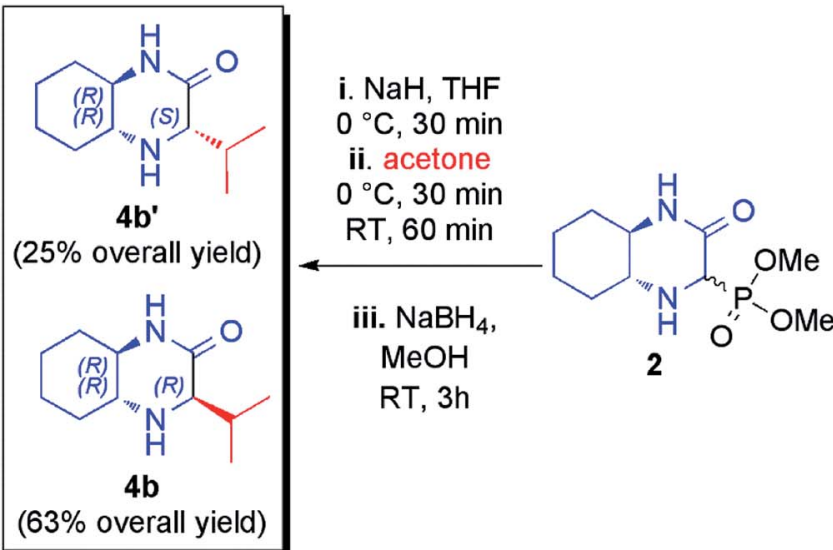

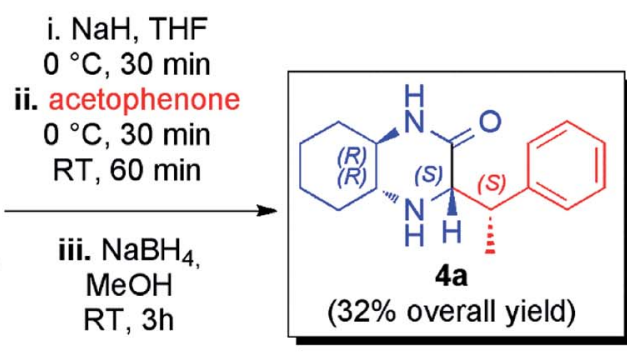

Scheme 2 HWE reactions involving acetophenone and acetone.

is recognized by positive bands at $c a .240$ and $200 \mathrm{~nm}$, and negative one at $c a .220 \mathrm{~nm}$ (Fig. 2). This observation clearly indicates the same AC of newly formed chirality centre at C-4.

To rationalize the experimental observations and assign the $\mathrm{AC}$ at $\mathrm{C}-4$, the TDDFT calculations were performed for $(1 R, 4 R, 6 R)$-6d using CAM-B3LYP/def2-TZVP level of theory including a polarizable continuum solvent model (PCM) for $\mathrm{CH}_{3} \mathrm{CN}$. These simulations were preceded by a detailed conformational search at the molecular mechanic level, and further re-optimization of the resultant structures at the DFT level by using the following combination: $\omega$ B97X-D/6$311+\mathrm{G}(\mathrm{d}, \mathrm{p}) / \mathrm{PCM} / \mathrm{CH}_{3} \mathrm{CN}$. For computational details, see Experimental part and Table S1/Fig. S1 and S2 in ESI $\dagger$ with structures of the most abundant conformers and their ECD spectra. As can be seen in Fig. 2, the calculated TDDFT spectrum perfectly stays in line with the experimental spectra. On<smiles>COP(=O)(OC)C1(CC(C)(C)C)N[C@@H]2CCCC[C@H]2NC1=S</smiles>

(6\% yield, $d r$ 93:7)

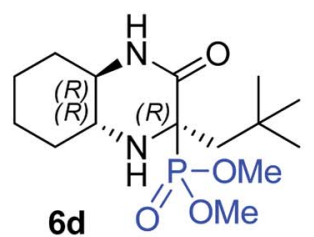

(87\% yield, $d r$ 92:8)<smiles>CC(C)(C)CC1=N[C@@H]2CCCC[C@H]2NC1=S</smiles>

6b (34\% yield)

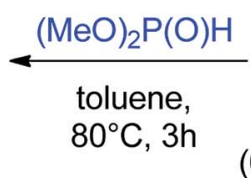<smiles>CC(C)(C)CC1=N[C@@H]2[C@@H](O)CCC[C@@H]2NC1=S</smiles>
(63\% yield) toluene, Lawesson's reflux, $4 \mathrm{~h}$ reagent

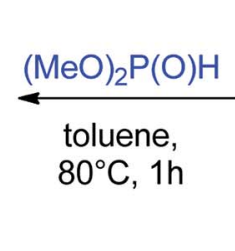<smiles>CC(C)(C)CC1=N[C@@H]2CCCC[C@H]2NC1=O</smiles>

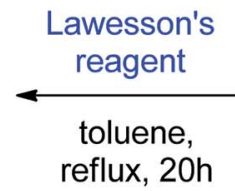
reflux, $20 \mathrm{~h}$ 5a

(79\% yield)
1. $\left[\left(\mathrm{CH}_{3}\right)_{3} \mathrm{SiO}\right]_{3} \mathrm{P}$ BrTMS $\mathrm{CH}_{2} \mathrm{Cl}_{2}, \mathrm{RT}, 120 \mathrm{~h}$

2. $\mathrm{MeOH}$ RT, $12 \mathrm{~h}$<smiles>CC(C)(C)C[C@H]1Nc2ccccc2NC1=S</smiles>

$6 c(51 \%$ yield $)$

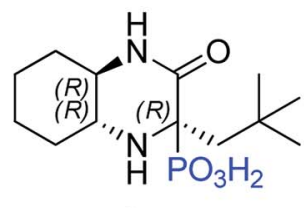

$6 \mathbf{e}$

(72\% yield, $d r$ 93:7)

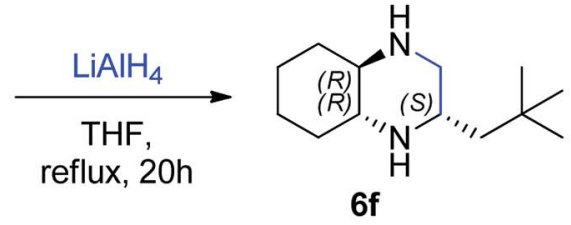

(67\% yield)

Scheme 3 The utility of imine $3 i$ as model substrate in further transformations. 


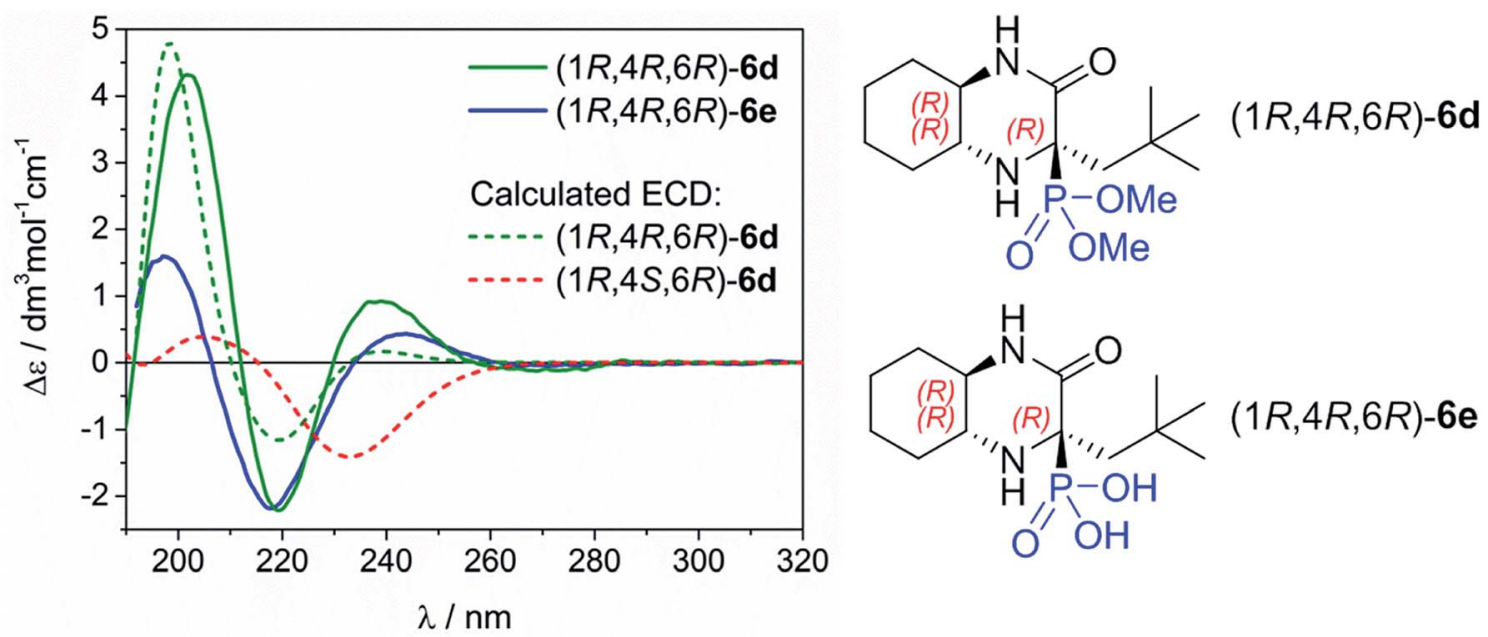

Fig. 2 Experimental ECD spectra of the main epimers of $6 \mathrm{~d}$ and $6 \mathrm{e}$ recorded in $\mathrm{CH}_{3} \mathrm{CN}$ compared to simulated spectrum for (1R,4R,6R)-6d and $(1 R, 4 S, 6 R)-6 \mathrm{~d}$ using CAM-B3LYP/def2-TZVP/PCM $\left(\mathrm{CH}_{3} \mathrm{CN}\right.$ ) level of theory (UV shift $=+17 \mathrm{~nm}, \sigma=0.3 \mathrm{eV}$ ).

the strength of this, we can assign the AC of newly formed chirality centre for epimers obtained in high diastereomeric excess as $4 R$. At the same time, we confirmed that the AC at C-4 for the minor epimer is $(4 S)$. To improve this statement the same computational procedure was applied for simulating ECD spectrum of $(1 R, 4 S, 6 R)$-6d. As a result, the obtained spectrum is contradictory to $(1 R, 4 R, 6 R)-\mathbf{6 d}$, which further supports our assignment.

\section{Conclusions}

In summary, we have developed an efficient protocol based on the Horner-Wadsworth-Emmons reaction of easily available hexahydroquionoxalin-2(1H)-one-derived phosphonate and a wide range of carbonyl substrates leading to new diastereomerically pure bicyclic imines and amines. In most cases, reaction led selectively to the desired imines that were isolated in good to excellent yields. Subsequent reduction of the pure imines or tautomeric imine/enamine mixtures provided corresponding chiral amines in very good yields. We have also demonstrated that the obtained chiral heterocyclic compounds could be applied as useful synthetic intermediates in the synthesis of other useful derivatives in highly asymmetric manner and using simple transformations.

\section{Experimental section}

\section{General information}

Melting points were determined on the Schmelzpunkt Bestimmer Apotec melting-point apparatus using the standard open capillary method and are uncorrected. ${ }^{1} \mathrm{H},{ }^{13} \mathrm{C}$ and ${ }^{31} \mathrm{P}$ NMR spectra were collected on Jeol 400yh, Bruker Avance III 500 and Bruker Avance II 600 instruments. NMR spectra recorded in $\mathrm{CDCl}_{3}, \mathrm{D}_{2} \mathrm{O}$ and were referenced to the respective residual ${ }^{1} \mathrm{H}$ or ${ }^{13} \mathrm{C}$ signals of the solvents. The reported $J$ values are those observed from the splitting patterns in the spectrum and may not reflect the true coupling constant values. NOESY experiments were carried out at $293 \mathrm{~K}$. Infrared spectra (4000$400 \mathrm{~cm}^{-1}$ ) were collected on a PerkinElmer 2000 FTIR spectrophotometer. High resolution mass spectra were collected using electrospray ionization on Waters LCT Premier XE TOF instrument. Optical rotations were measured using an Optical Activity Ltd. Model AA-5 automatic polarimeter; $[\alpha]^{\mathrm{D}}$ values are given in $10^{-1} \mathrm{deg} \mathrm{cm}^{2} \mathrm{~g}^{-1}$. Chromatographic separations were performed on silica gel 60 (70-230 mesh). Thin layer chromatography was carried out using silica gel 60 precoated plates.

\section{General procedure A for synthesis of cyclic imines $3 a-s$}

Sodium hydride ( $60 \%$ dispersion in mineral oil, $1.30 \mathrm{mmol}$, $52.0 \mathrm{mg}, 1.30$ equiv.) was dispersed in anhydrous THF $(10 \mathrm{~mL})$ under argon atmosphere. The mixture was cooled to $273 \mathrm{~K}$ in an ice bath and then dimethyl-[(1R,6R)-3-oxo-2,5-diazabicyclo [4.4.0]dec-4-yl]phosphonate 2 ( $1.10 \mathrm{mmol}, 288 \mathrm{mg}, 1.10$ equiv.) was added. The mixture was stirred for 30 minutes. The aldehyde was added (1.00 mmol, 1.00 equiv.) and the reaction continued for 30 minutes in $273 \mathrm{~K}$ and then for 60 minutes in a room temperature. Reaction mixture was washed with $\mathrm{Et}_{2} \mathrm{O}$ $(20 \mathrm{~mL})$ and saturated $\mathrm{NaHCO}_{3}$ solution $(20 \mathrm{~mL})$. The organic layer was dried $\left(\mathrm{Na}_{2} \mathrm{SO}_{4}\right)$, filtered and evaporated under reduced pressure. Depending on yield and purity of crude product, the imines were described without additional purification or purified by silica gel column chromatography (eluent: $\mathrm{CH}_{2} \mathrm{Cl}_{2}$ / МeOH $97: 3 \mathrm{v} / \mathrm{v})$.

\section{General procedure B for synthesis of amines $4 a-b$}

Sodium hydride (60\% dispersion in mineral oil, $1.30 \mathrm{mmol}$, $52.0 \mathrm{mg}, 1.30$ equiv.) was dispersed in anhydrous THF $(10 \mathrm{~mL})$ under argon atmosphere. The mixture was cooled to $273 \mathrm{~K}$ in an ice bath and then dimethyl-[(1R,6R)-3-oxo-2,5-diazabicyclo [4.4.0]dec-4-yl]phosphonate 2 ( $1.10 \mathrm{mmol}, 288 \mathrm{mg}, 1.10$ equiv.) was added. The mixture was stirred for 30 minutes. The ketone (acetophenone or acetone) was added ( $1.00 \mathrm{mmol}, 1.00$ equiv.) and the reaction continued for 30 minutes in $273 \mathrm{~K}$ and then for 
60 minutes in a room temperature. Reaction mixture was washed with $\mathrm{Et}_{2} \mathrm{O}(20 \mathrm{~mL})$ and saturated $\mathrm{NaHCO}_{3}$ solution (20 $\mathrm{mL})$. The organic layer was dried $\left(\mathrm{Na}_{2} \mathrm{SO}_{4}\right)$, filtered and evaporated under reduced pressure. The crude product was then dissolved in methanol $(10 \mathrm{~mL})$ at room temperature and sodium borohydride $(1.30 \mathrm{mmol}, 49.2 \mathrm{mg}, 1.30$ equiv. was added). The mixture was stirred for 3 hours. Solvent was evaporated under reduced pressure and the residue was subjected to column chromatography (eluent : $\mathrm{CH}_{2} \mathrm{Cl}_{2} / \mathrm{MeOH} 95: 5 \mathrm{v} / \mathrm{v}$ ) to obtain pure amines.

\section{General procedure $\mathrm{C}$ for synthesis of amines $5 \mathrm{a}-\mathrm{e}$ and $6 \mathrm{c}$}

To a solution of an appropriate imine ( $1.00 \mathrm{mmol}, 1.00$ equiv.) in methanol $(10 \mathrm{~mL})$ at room temperature was added sodium borohydride ( $1.30 \mathrm{mmol}, 49.2 \mathrm{mg}, 1.30$ equiv.). The mixture was stirred for 3 hours. Solvent was evaporated under reduced pressure and the residue was subjected to column chromatography (eluent : $\mathrm{CH}_{2} \mathrm{Cl}_{2} / \mathrm{MeOH} 95: 5 \mathrm{v} / \mathrm{v}$ ) to obtain pure diastereomers of amine.

\section{Procedure $D$ for the synthesis of $6 b$}

To a solution of imine $3 \mathbf{i}$ ( $2.00 \mathrm{mmol}, 444 \mathrm{mg}, 2.00$ equiv.) in toluene (15 mL), Lawesson's reagent (1.20 mmol, $485 \mathrm{mg}, 0.600$ equiv.) was added under an argon atmosphere. The reaction mixture was refluxed for 4 hours. Upon completion of the reaction (monitored by TLC), it was quenched with water (20 $\mathrm{mL})$ and extracted with ethyl acetate $(3 \times 20 \mathrm{~mL})$. The organic layer was dried over $\mathrm{Na}_{2} \mathrm{SO}_{4}$, filtered, and concentrated under reduced pressure. The crude product was purified by column chromatography (eluent : $\mathrm{CH}_{2} \mathrm{Cl}_{2} / \mathrm{MeOH} 98: 2 \mathrm{v} / \mathrm{v}$ ).

\section{Procedure $\mathrm{E}$ for the synthesis of dialkyl aminophosphonic acid ester $6 \mathrm{~d}$ and aminophosphonic acid $6 \mathrm{e}$}

Procedure E for the synthesis of dialkyl aminophosphonic acid ester $\mathbf{6 d}$ and aminophosphonic acid $\mathbf{6 e}$ can be found in the literature. ${ }^{10 b}$

\section{Procedure $F$ for reduction of 5 a to bisamine $6 f$}

To a solution of $5 \mathrm{a}(0.500 \mathrm{mmol}, 112 \mathrm{mg}, 1.0$ equiv. $)$ in anhydrous THF $(5 \mathrm{~mL})$ under argon atmosphere was added lithium aluminium hydride ( $0.750 \mathrm{mmol}, 28.5 \mathrm{mg}, 1.5$ equiv.). The mixture was heated under reflux for 20 hours and then cooled down to room temperature. The reaction was quenched with addition of water $(30 \mu \mathrm{L}), \mathrm{NaOH}(15 \%$ solution, $30 \mu \mathrm{L})$ and water $(90 \mu \mathrm{L})$. Resulting suspension was filtered through Celite and washed with THF. The organic layer was dried $\left(\mathrm{K}_{2} \mathrm{CO}_{3}\right)$, filtered and evaporated under reduced pressure and the resulting crude product was purified by column chromatography (eluent : $\mathrm{CH}_{2} \mathrm{Cl}_{2} / \mathrm{MeOH} 80: 20 \mathrm{v} / \mathrm{v}$ ).

4-Octyl-(1R,6R)-3-oxo-2,5-diazabicyclo[4.4.0]dec-4-ene (3e). Using general procedure A; colorless oil; $238 \mathrm{mg}$; yield $=90 \%$; $[\alpha]_{\mathrm{D}}^{20}-109\left(c 1.05, \mathrm{CH}_{2} \mathrm{Cl}_{2}\right.$ ); IR (KBr): 724, 1119, 1220, 1318, 1364, 1455, 1628, 1683, 2857, 2927, 3085, $3205 \mathrm{~cm}^{-1} ;{ }^{1} \mathrm{H}$ NMR $\left(400 \mathrm{MHz}, \mathrm{CDCl}_{3}\right): \delta 6.24$ (br. s, $\left.1 \mathrm{H}\right), 2.98-3.11(\mathrm{~m}, 2 \mathrm{H}), 2.59-$ 2.67 (m, 1H), 2.42-2.50 (m, 1H), 2.29-2.31 (m, 1H), 1.75-1.89 (m, 3H), 1.49-1.59 (m, 2H), 1.19-1.41 (m, 14H), $0.85(\mathrm{t}, J=$ $7.3 \mathrm{~Hz}, 3 \mathrm{H}) ;{ }^{13} \mathrm{C} \mathrm{NMR}\left(100 \mathrm{MHz}, \mathrm{CDCl}_{3}\right): \delta 166.1,158.7,62.5$, 54.4, 33.9, 31.9, 31.8, 31.2, 29.5, 29.4, 29.3, 27.0, 25.3, 23.8, 22.7, 14.2; HRMS (ESI-TOF) calcd for $\mathrm{C}_{16} \mathrm{H}_{28} \mathrm{~N}_{2} \mathrm{O}[\mathrm{M}+\mathrm{H}]^{+} \mathrm{m} / z$ : 265.2280, found: 265.2274 .

4-(2-Ethylbutyl)-(1R,6R)-3-oxo-2,5-diazabicyclo[4.4.0]dec-4-ene (3h). Using general procedure A; off-white solid; $196 \mathrm{mg}$; yield = 83\%; mp 87-90 ${ }^{\circ} \mathrm{C}$; $[\alpha]_{\mathrm{D}}^{20}-98$ (c 0.46, $\left.\mathrm{CH}_{2} \mathrm{Cl}_{2}\right)$; IR (KBr): 811, 1226, 1363, 1456, 1621, 1686, 2856, 2931, 2959, 3068, $3189 \mathrm{~cm}^{-1} ;{ }^{1} \mathrm{H}$ NMR (400 MHz, $\mathrm{CDCl}_{3}$ ): $\delta 6.38$ (br. s, $\left.1 \mathrm{H}\right), 2.98-3.09(\mathrm{~m}, 2 \mathrm{H}), 2.72$ (ddd, $J=2.5,6.4,16.1 \mathrm{~Hz}, 1 \mathrm{H}), 2.24-2.32(\mathrm{~m}, 2 \mathrm{H}), 1.69-1.90(\mathrm{~m}$, $4 \mathrm{H}), 1.24-1.41(\mathrm{~m}, 8 \mathrm{H}), 0.85(\mathrm{t}, J=7.6 \mathrm{~Hz}, 3 \mathrm{H}), 0.83(\mathrm{t}, J=7.3 \mathrm{~Hz}$, $3 \mathrm{H}) ;{ }^{13} \mathrm{C}$ NMR $\left(100 \mathrm{MHz}, \mathrm{CDCl}_{3}\right): \delta 165.9,158.8,62.6,54.4,38.5$, $37.8,31.9,31.1,25.7,25.3,25.27,23.8,10.9,10.7$; HRMS (ESITOF) calcd for $\mathrm{C}_{14} \mathrm{H}_{24} \mathrm{~N}_{2} \mathrm{O}[\mathrm{M}+\mathrm{H}]^{+} \mathrm{m} / z$ : 237.1967, found: 237.1971.

4-Neopentyl-(1R,6R)-3-oxo-2,5-diazabicyclo[4.4.0]dec-4-ene (3i). Using general procedure A; colorless solid; $140 \mathrm{mg}$; yield $=63 \%$; mp 129-131 ${ }^{\circ} \mathrm{C}$; $[\alpha]_{\mathrm{D}}^{20}-103$ (c 1.05, $\mathrm{CH}_{2} \mathrm{Cl}_{2}$ ); IR (KBr): 819, 1219, 1316, 1366, 1450, 1611, 1677, 2864, 2941, 3090, $3188 \mathrm{~cm}^{-1} ;{ }^{1} \mathrm{H}$ NMR (400 MHz, $\left.\mathrm{CDCl}_{3}\right): \delta 6.30$ (br. s, $\left.1 \mathrm{H}\right), 3.04-3.07$ (m, 3H), 2.33$2.36(\mathrm{~m}, 1 \mathrm{H}), 2.05(\mathrm{~d}, J=12.2 \mathrm{~Hz}, 1 \mathrm{H}), 1.76-1.91(\mathrm{~m}, 3 \mathrm{H}), 1.30-1.42$ $(\mathrm{m}, 4 \mathrm{H}), 0.94(\mathrm{~s}, 9 \mathrm{H}) ;{ }^{13} \mathrm{C}$ NMR (100 MHz, $\left.\mathrm{CDCl}_{3}\right): \delta$ 165.4, 159.2, 62.9, 54.7, 44.6, 31.9 (2C overlapped), 31.0, 29.8 (3C overlapped), 25.2, 23.8; HRMS (ESI-TOF) calcd for $\mathrm{C}_{13} \mathrm{H}_{23} \mathrm{~N}_{2} \mathrm{O}[\mathrm{M}+\mathrm{H}]^{+} \mathrm{m} / \mathrm{z}$ : 223.1810, found: 223.1807 .

4-Cyclopentylmethyl-(1R,6R)-3-oxo-2,5-diazabicyclo[4.4.0]dec-4ene (3k). Using general procedure A; off-white solid; $185 \mathrm{mg}$; yield $=79 \%$; mp 121-123 ${ }^{\circ} \mathrm{C} ;[\alpha]_{\mathrm{D}}^{20}-105\left(c 0.66, \mathrm{CH}_{2} \mathrm{Cl}_{2}\right)$; IR (KBr): 802, 1052, 1358, 1628, 1686, 2858, 2932, 3068, $3189 \mathrm{~cm}^{-1} ;{ }^{1} \mathrm{H}$ NMR $(400$ $\mathrm{MHz}, \mathrm{CDCl}_{3}$ ): $\delta 6.24$ (br. s, $\left.1 \mathrm{H}\right), 2.99-3.09$ (m, 2H), 2.79 (ddd, $J=$ 13.5, 6.7, $2.1 \mathrm{~Hz}, 1 \mathrm{H}), 2.29-2.39$ (m, 2H), 2.17 (sept, $J=7.3 \mathrm{~Hz}, 1 \mathrm{H}$ ), 1.14-1.89 (m, 15H); ${ }^{13} \mathrm{C}$ NMR (100 MHz, $\left.\mathrm{CDCl}_{3}\right): \delta$ 165.7, 158.8, 62.5, 54.5, 39.6, 37.8, 32.6, 32.1, 31.9, 31.1, 25.2, 25.1, 25.0, 23.8; HRMS (ESI-TOF) calcd for $\mathrm{C}_{14} \mathrm{H}_{22} \mathrm{~N}_{2} \mathrm{O}[\mathrm{M}+\mathrm{H}]^{+} m / z: 235.1810$, found: 235.1813 .

4-Cyclohexylmethyl-(1R,6R)-3-oxo-2,5-diazabicyclo[4.4.0]dec4-ene (3l). Using general procedure A; colorless solid; $169 \mathrm{mg}$; yield $=68 \%$; mp $124-125{ }^{\circ} \mathrm{C}$; $[\alpha]_{\mathrm{D}}^{20}-104\left(c 0.98, \mathrm{CH}_{2} \mathrm{Cl}_{2}\right)$; IR (KBr): 810, 1222, 1364, 1444, 1618, 1677, 2851, 2931, 3065, 3095, $3184 \mathrm{~cm}^{-1}$; ${ }^{1} \mathrm{H}$ NMR (400 MHz, $\mathrm{CDCl}_{3}$ ): $\delta 6.31$ (br. s, $1 \mathrm{H}$ ), 3.02$3.10(\mathrm{~m}, 2 \mathrm{H}), 2.69$ (ddd, $J=13.3,6.3,1.8 \mathrm{~Hz}, 1 \mathrm{H}), 2.28-2.36(\mathrm{~m}$, $1 \mathrm{H}), 2.22(\mathrm{dd}, J=13.1,7.6 \mathrm{~Hz}, 1 \mathrm{H}), 1.59-1.89(\mathrm{~m}, 8 \mathrm{H}), 1.09-1.41$ $(\mathrm{m}, 8 \mathrm{H}), 0.88-1.02(\mathrm{~m}, 2 \mathrm{H}) ;{ }^{13} \mathrm{C} \mathrm{NMR}\left(100 \mathrm{MHz} \mathrm{CDCl}_{3}\right): \delta 165.6$, 158.8, 62.5, 54.5, 41.1, 36.2, 33.5, 33.0, 31.9, 31.1, 26.4, 26.3, 26.2 25.2, 23.7; HRMS (ESI-TOF) calcd for $\mathrm{C}_{15} \mathrm{H}_{24} \mathrm{~N}_{2} \mathrm{O}[\mathrm{M}+\mathrm{H}]^{+}$ $\mathrm{m} / z: 249.1967$, found: 249.1960 .

4-Phenethyl-(1R,6R)-3-oxo-2,5-diazabicyclo[4.4.0]dec-4-ene (3m). Known compound; using general procedure A; pale yellow solid; 179 mg; yield = 70\%; mp 127-128 ${ }^{\circ} \mathrm{C} ;[\alpha]_{\mathrm{D}}^{20}-110\left(\right.$ c 0.55, $\left.\mathrm{CH}_{2} \mathrm{Cl}_{2}\right)$; IR (KBr): 499, 711, 756, 1358, 1624, 1678, 2863, 2934, 3064, $3188 \mathrm{~cm}^{-1}$; ${ }^{1} \mathrm{H}$ NMR (400 MHz, $\mathrm{CDCl}_{3}$ ): $\delta$ 7.14-7.28 (m, 5H), 6.52 (br. s, $1 \mathrm{H}$ ), 2.82-3.03 (m, 6H), 2.29-2.32 (m, 1H), 1.76-1.90 (m, 3H), 1.25-1.41 $(\mathrm{m}, 4 \mathrm{H}) ;{ }^{13} \mathrm{C} \mathrm{NMR}\left(100 \mathrm{MHz}, \mathrm{CDCl}_{3}\right): \delta 164.9,158.6,141.5,128.7$ (2C overlapped), 128.4 (2C overlapped), 126.0, 62.6, 54.4, 35.4, 32.7, 31.2, 31.1, 25.3, 23.8; HRMS (ESI-TOF) calcd for $\mathrm{C}_{16} \mathrm{H}_{21} \mathrm{~N}_{2} \mathrm{O}[\mathrm{M}+\mathrm{H}]^{+} \mathrm{m} / z$ : 257.1654, found: 257.1647 . 
4-Phenylpropyl-(1R,6R)-3-oxo-2,5-diazabicyclo[4.4.0]dec-4-ene (3n). Using general procedure A; off-white solid; $265 \mathrm{mg}$; yield = 98\%; mp 115-117 ${ }^{\circ} \mathrm{C}$; $[\alpha]_{\mathrm{D}}^{20}-93\left(c 0.40, \mathrm{CH}_{2} \mathrm{Cl}_{2}\right)$; IR (KBr): 701, 756, 1360, 1451, 1494, 1627, 1684, 2855, 2926, 3023, 3081, $3171 \mathrm{~cm}^{-1} ;{ }^{1} \mathrm{H}$ NMR (400 MHz, $\left.\mathrm{CDCl}_{3}\right): \delta 7.13-7.27(\mathrm{~m}, 5 \mathrm{H}), 6.20$ (br. s, 1H), 2.97-3.04 (m, 2H), 2.68 (q, $J=6.7 \mathrm{~Hz}, 1 \mathrm{H}), 2.66(\mathrm{t}, J=$ $7.6 \mathrm{~Hz}, 2 \mathrm{H}), 2.57$ (q, $J=7.6 \mathrm{~Hz}, 1 \mathrm{H}), 2.29-2.31$ (m, 1H), 1.69-1.94 (m, 5H), 1.24-1.41 (m, 4H); ${ }^{13} \mathrm{C}$ NMR (100 MHz, $\left.\mathrm{CDCl}_{3}\right): \delta 165.5$, 158.6, 142.2, 128.6 (2C overlapped), 128.4 (2C overlapped), 125.8, 62.5, 54.4, 35.7, 33.5, 31.9, 31.2, 28.5, 25.3, 23.8; HRMS (ESI-TOF) calcd for $\mathrm{C}_{17} \mathrm{H}_{22} \mathrm{~N}_{2} \mathrm{O}[\mathrm{M}+\mathrm{H}]^{+} \mathrm{m} / z$ : 271.1810, found: 271.1806 .

4-(3-Phenylbutyl)-(1R,6R)-3-oxo-2,5-diazabicyclo[4.4.0]dec-4ene (3o). Using general procedure A; off-white solid; $196 \mathrm{mg}$; yield $=69 \%$; mixture of epimers $1: 1$; mp 93-95 ${ }^{\circ} \mathrm{C}$; IR $(\mathrm{KBr})$ : 696, 760, 1369, 1452, 1493, 1628, 1684, 2858, 2927, 3027, 3062, $3195 \mathrm{~cm}^{-1} ;{ }^{1} \mathrm{H}$ NMR $\left(400 \mathrm{MHz}, \mathrm{CDCl}_{3}\right): \delta 7.13-7.28(\mathrm{~m}, 5 \mathrm{H}), 5.96$ (br. s, 1H), 2.91-3.00 (m, 2H), 2.74 (sext, $J=7.6 \mathrm{~Hz}, 1 \mathrm{H}), 2.50$ (q, $J=6.1 \mathrm{~Hz}, 1 \mathrm{H}), 2.27-2.30(\mathrm{~m}, 1 \mathrm{H}), 1.62-1.94(\mathrm{~m}, 5 \mathrm{H}), 1.21-1.41$ $(\mathrm{m}, 5 \mathrm{H}), 1.27$ (dd, $J=7.0,2.3 \mathrm{~Hz}, 3 \mathrm{H}),{ }^{13} \mathrm{C} \mathrm{NMR}(100 \mathrm{MHz}$, $\mathrm{CDCl}_{3}$ ): $\delta 165.7,158.5,147.1,128.4$ (2C overlapped), 127.2 (2C overlapped), 126.0, 62.5, 54.3, 40.0, 34.9, 32.1, 31.9, 31.1, 25.3, 23.8, 22.3; HRMS (ESI-TOF) calcd for $\mathrm{C}_{18} \mathrm{H}_{24} \mathrm{~N}_{2} \mathrm{O}[\mathrm{M}+\mathrm{H}]^{+} \mathrm{m} / z$ : 285.1967, found: 285.1963.

Full characteristic of compounds $\mathbf{3 b}, \mathbf{3 d}$ and $\mathbf{3 g}$ can be found in our previous paper. ${ }^{10 a}$

4-((S)-1-Phenylethyl)-(1R,4S,6R)-3-oxo-2,5-diazabicyclo[4.4.0] decane (4a). Using general procedure B; colorless oil; $83 \mathrm{mg}$; yield $=32 \% ;[\alpha]_{\mathrm{D}}^{20}-16\left(c 0.25, \mathrm{CH}_{2} \mathrm{Cl}_{2}\right)$; IR (KBr): 706, 772, 1121, 1343, 1357, 1452, 1664, 2855, 2929, 3178, $3447 \mathrm{~cm}^{-1} ;{ }^{1} \mathrm{H}$ NMR (400 $\left.\mathrm{MHz} \mathrm{CDCl}_{3}\right): \delta 7.31-7.34(\mathrm{~m}, 2 \mathrm{H}), 7.23-7.28(\mathrm{~m}, 2 \mathrm{H}), 7.18-7.21$ (m, 1H), 5.95 (br. s, $1 \mathrm{H}), 3.78(\mathrm{dq}, J=7.3,3.4 \mathrm{~Hz}, 1 \mathrm{H}), 3.72(\mathrm{~d}, J=$ $3.1 \mathrm{~Hz}, 1 \mathrm{H}), 2.37-2.41(\mathrm{~m}, 2 \mathrm{H}), 1.60-1.85(\mathrm{~m}, 4 \mathrm{H}), 1.45$ (d, $J=$ $7.3 \mathrm{~Hz}, 3 \mathrm{H}), 0.99-1.34(\mathrm{~m}, 5 \mathrm{H}) ;{ }^{13} \mathrm{C} \mathrm{NMR}$ (100 $\mathrm{MHz}, \mathrm{CDCl}_{3}$ ): $\delta$ 171.7, 141.7, 128.7 (2C overlapped), 128.2 (2C overlapped), 126.7, 64.4, 57.9, 57.7, 40.2, 31.6, 30.9, 24.9, 23.7, 18.1; HRMS (ESI-TOF) calcd for $\mathrm{C}_{16} \mathrm{H}_{23} \mathrm{~N}_{2} \mathrm{O}[\mathrm{M}+\mathrm{H}]^{+} \mathrm{m} / z$ : 259.1810, found: 259.1812.

4-Isopropyl-(1R,4R,6R)-3-oxo-2,5-diazabicyclo[4.4.0]decane (4b). Using general procedure B; colorless solid; $123 \mathrm{mg}$; yield $=63 \%$; mp 126-127 ${ }^{\circ} \mathrm{C}$; $[\alpha]_{\mathrm{D}}^{20}+27\left(c 0.30, \mathrm{CH}_{2} \mathrm{Cl}_{2}\right)$; IR (KBr): 1157, 1364, 1464, 1643, 2862, 2935, 3188, 3327, $3449 \mathrm{~cm}^{-1} ;{ }^{1} \mathrm{H}$ NMR $(400 \mathrm{MHz}$, $\mathrm{CDCl}_{3}$ ): $\delta 6.89$ (br. s, $\left.1 \mathrm{H}\right), 3.41(\mathrm{~s}, 1 \mathrm{H}), 2.92-2.98(\mathrm{~m}, 1 \mathrm{H}), 2.42-2.48$ $(\mathrm{m}, 1 \mathrm{H}), 1.73-1.93(\mathrm{~m}, 5 \mathrm{H}), 1.15-1.46(\mathrm{~m}, 4 \mathrm{H}), 1.30(\mathrm{~s}, 3 \mathrm{H}), 1.25$ (s, $3 \mathrm{H}), 1.02-1.15(\mathrm{~m}, 1 \mathrm{H}) ;{ }^{13} \mathrm{C} \mathrm{NMR}\left(100 \mathrm{MHz}, \mathrm{CDCl}_{3}\right): \delta 173.1,73.5$, 63.5, 59.0, 55.8, 31.2, 30.8, 27.4, 26.6, 25.0, 23.7; HRMS (ESI-TOF) calcd for $\mathrm{C}_{11} \mathrm{H}_{21} \mathrm{~N}_{2} \mathrm{O}[\mathrm{M}+\mathrm{H}]^{+} \mathrm{m} / z: 197.1654$, found: 197.1649 .

4-Isopropyl-(1R,4S,6R)-3-oxo-2,5-diazabicyclo[4.4.0]decane

$\left(\mathbf{4} \mathbf{b}^{\prime}\right)$. Using general procedure $\mathrm{B}$; colorless solid; $49 \mathrm{mg}$; yield = 25\%; mp 120-122 ${ }^{\circ} \mathrm{C}$; $[\alpha]_{\mathrm{D}}^{20}+33\left(c 0.30, \mathrm{CH}_{2} \mathrm{Cl}_{2}\right)$; IR (KBr): 827, 1352, 1364, 1465, 1658, 2860, 2931, 3195, 3321, $3418 \mathrm{~cm}^{-1} ;{ }^{1} \mathrm{H}$ NMR (400 $\mathrm{MHz}, \mathrm{CDCl}_{3}$ ): $\delta 6.04$ (br. s, $\left.1 \mathrm{H}\right), 3.32$ (d, $\left.J=4.6 \mathrm{~Hz}, 1 \mathrm{H}\right), 2.94-3.00$ (m, 1H), 2.48-2.54 (m, 1H), 2.39 (dsep, $J=7.0,4.9 \mathrm{~Hz}, 1 \mathrm{H}), 1.69-$ $1.88(\mathrm{~m}, 5 \mathrm{H}), 1.08-1.38(\mathrm{~m}, 4 \mathrm{H}), 1.03$ (d, $J=7.0 \mathrm{~Hz}, 3 \mathrm{H}), 0.93(\mathrm{~d}, J=$ $7.0 \mathrm{~Hz}, 3 \mathrm{H}) ;{ }^{13} \mathrm{C} \mathrm{NMR}\left(100 \mathrm{MHz}, \mathrm{CDCl}_{3}\right): \delta 172.6,77.3,62.5,58.9$, 55.9, 31.6, 31.0, 24.9, 23.8, 20.3, 18.6; HRMS (ESI-TOF) calcd for $\mathrm{C}_{11} \mathrm{H}_{21} \mathrm{~N}_{2} \mathrm{O}[\mathrm{M}+\mathrm{H}]^{+} m / z: 197.1654$, found: 197.1649 .
4-Neopentyl-(1R,4S,6R)-3-oxo-2,5-diazabicyclo[4.4.0]decane (5a). Using general procedure C; colorless solid; $177 \mathrm{mg}$; yield = 79\%; mp 182-184 ${ }^{\circ} \mathrm{C}$; $[\alpha]_{\mathrm{D}}^{20}-31\left(c 0.16, \mathrm{CH}_{2} \mathrm{Cl}_{2}\right)$; IR (KBr): 1144, 1359, 1409, 1476, 1658, 2862, 2938, 3065, 3189, $3282 \mathrm{~cm}^{-1} ;{ }^{1} \mathrm{H}$ NMR (400 MHz, $\mathrm{CDCl}_{3}$ ): $\delta 5.78$ (br. s, $1 \mathrm{H}$ ), 3.50 (dd, $J=8.4$, $1.8 \mathrm{~Hz}, 1 \mathrm{H}), 2.97-3.03(\mathrm{~m}, 1 \mathrm{H}), 2.45-2.51(\mathrm{~m}, 1 \mathrm{H}), 2.23(\mathrm{dd}, J=$ $14.5,2.5 \mathrm{~Hz}, 1 \mathrm{H}), 1.68-1.81(\mathrm{~m}, 4 \mathrm{H}), 1.22-1.41(\mathrm{~m}, 6 \mathrm{H}), 0.97(\mathrm{~s}$, $9 \mathrm{H}) ;{ }^{13} \mathrm{C} \mathrm{NMR}\left(100 \mathrm{MHz}, \mathrm{CDCl}_{3}\right): \delta 173.1,58.7,58.5,58.3,46.0$, 31.7, 31.0, 30.6, 30.1 (3C overlapped), 24.8, 23.9; HRMS (ESITOF) calcd for $\mathrm{C}_{13} \mathrm{H}_{25} \mathrm{~N}_{2} \mathrm{O}[\mathrm{M}+\mathrm{H}]^{+} \mathrm{m} / z$ : 225.1967, found: 225.1964 .

4-Neopentyl-(1R,4R,6R)-3-oxo-2,5-diazabicyclo[4.4.0]decane $(\mathbf{5 a})$. Using general procedure C; colorless solid; $43 \mathrm{mg}$; yield = 19\%; mp 178-179 ${ }^{\circ} \mathrm{C} ;[\alpha]_{\mathrm{D}}^{20}+32\left(c 0.14, \mathrm{CH}_{2} \mathrm{Cl}_{2}\right)$; IR (KBr): 1120, 1362, 1408, 1467, 1659, 2860, 2936, 3058, 3180, $3300 \mathrm{~cm}^{-1} ;{ }^{1} \mathrm{H}$ NMR (400 MHz, $\mathrm{CDCl}_{3}$ ): $\delta 5.70$ (br. s, $\left.1 \mathrm{H}\right), 3.60$ (dd, $J=9.2$, $4.5 \mathrm{~Hz}, 1 \mathrm{H}), 2.93-2.99$ (m, 1H), 2.51-2.57 (m, 1H), 1.70-1.81 (m, $5 \mathrm{H}), 1.60$ (dd, $J=14.4,9.2 \mathrm{~Hz}, 1 \mathrm{H}), 1.54$ (br. s, $1 \mathrm{H}), 1.12-1.40$ (m, $4 \mathrm{H}), 0.99$ (s, 9H); ${ }^{13} \mathrm{C} \mathrm{NMR}\left(100 \mathrm{MHz}, \mathrm{CDCl}_{3}\right): \delta 174.1,59.0,56.4$, 53.1, 46.3, 31.8, 31.1, 31.0, 29.9 (3C overlapped), 25.0, 23.9; HRMS (ESI-TOF) calcd for $\mathrm{C}_{13} \mathrm{H}_{25} \mathrm{~N}_{2} \mathrm{O}[\mathrm{M}+\mathrm{H}]^{+} \mathrm{m} / z$ : 225.1967, found: 225.1964 .

4-(Cyclohexylmethyl)-(1R,4S,6R)-3-oxo-2,5-diazabicyclo[4.4.0] decane (5b). Using general procedure C; colorless solid; $130 \mathrm{mg}$; yield $=52 \% ; \operatorname{mp~} 155-156{ }^{\circ} \mathrm{C} ;[\alpha]_{\mathrm{D}}^{20}+55\left(c 0.29, \mathrm{CH}_{2} \mathrm{Cl}_{2}\right)$; IR $(\mathrm{KBr})$ : 1131, 1146, 1313, 1353, 1412, 1449, 1661, 2852, 2922, 3063, 3187, $3272 \mathrm{~cm}^{-1} ;{ }^{1} \mathrm{H}$ NMR $\left(400 \mathrm{MHz}, \mathrm{CDCl}_{3}\right.$ ): $\delta 6.08$ (br. s, $1 \mathrm{H}$ ), 3.56 (dd, $J=9.6,3.4 \mathrm{~Hz}, 1 \mathrm{H}), 2.98-3.03(\mathrm{~m}, 1 \mathrm{H}), 2.45-2.51(\mathrm{~m}, 1 \mathrm{H}), 1.93$ (ddd, $J=13.8,10.0,3.4 \mathrm{~Hz}, 1 \mathrm{H}), 1.64-1.86(\mathrm{~m}, 10 \mathrm{H}), 1.11-1.52$ (m, 9H), 0.85-1.03 (m, 2H); ${ }^{13} \mathrm{C}$ NMR (100 MHz, $\left.\mathrm{CDCl}_{3}\right): \delta 173.0,58.5$, 58.2, 56.9, 39.9, 34.4, 33.8, 31.9, 31.6, 30.8, 26.6, 26.4, 26.2, 24.8, 23.8; HRMS (ESI-TOF) calcd for $\mathrm{C}_{15} \mathrm{H}_{27} \mathrm{~N}_{2} \mathrm{O}[\mathrm{M}+\mathrm{H}]^{+} \mathrm{m} / \mathrm{z}$ : 251.2123, found: 251.2118 .

4-(Cyclohexylmethyl)-(1R,4R,6R)-3-oxo-2,5-diazabicyclo[4.4.0] decane $\left(5 \mathbf{b}^{\prime}\right)$. Using general procedure C; colorless solid; $83 \mathrm{mg}$; yield $=33 \%$; mp $174-175{ }^{\circ} \mathrm{C} ;[\alpha]_{\mathrm{D}}^{20}+46\left(c 0.34, \mathrm{CH}_{2} \mathrm{Cl}_{2}\right)$; IR $(\mathrm{KBr})$ : 1114, 1148, 1359, 1413, 1448, 1659, 2851, 2928, 3058, 3178, $3298 \mathrm{~cm}^{-1}{ }^{1}{ }^{\mathrm{H}} \mathrm{NMR}\left(400 \mathrm{MHz}, \mathrm{CDCl}_{3}\right.$ ): $\delta 6.18$ (br. s, $1 \mathrm{H}$ ), 3.56 (dd, $J=7.2,7.0 \mathrm{~Hz}, 1 \mathrm{H}), 2.93-2.99(\mathrm{~m}, 1 \mathrm{H}), 2.48-2.54(\mathrm{~m}, 1 \mathrm{H}), 1.60-$ $1.81(\mathrm{~m}, 12 \mathrm{H}), 1.08-1.30(\mathrm{~m}, 8 \mathrm{H}), 0.84-1.04(\mathrm{~m}, 2 \mathrm{H}) ;{ }^{13} \mathrm{C}$ NMR $\left(100 \mathrm{MHz}, \mathrm{CDCl}_{3}\right): \delta 174.0,58.9,55.6,52.9,39.9,34.3,34.2,31.9$, 31.6, 31.0, 26.6, 26.4, 26.1, 25.0, 23.9; HRMS (ESI-TOF) calcd for $\mathrm{C}_{15} \mathrm{H}_{27} \mathrm{~N}_{2} \mathrm{O}[\mathrm{M}+\mathrm{H}]^{+} m / z: 251.2123$, found: 251.2118 .

\section{4-(3-Phenylpropyl)-(1R,4R,6R)-3-oxo-2,5-diazabicyclo[4.4.0]}

decane (5c). Using general procedure $\mathrm{C}$; colorless solid; $114 \mathrm{mg}$; yield $=42 \%$; mp $134-135{ }^{\circ} \mathrm{C} ;[\alpha]_{\mathrm{D}}^{20}+36\left(c 0.70, \mathrm{CH}_{2} \mathrm{Cl}_{2}\right)$; IR $(\mathrm{KBr})$ : 696, 752, 1364, 1417, 1452, 1496, 1655, 2857, 2931, 3059, 3174, $3296 \mathrm{~cm}^{-1} ;{ }^{1} \mathrm{H}$ NMR (400 MHz, $\mathrm{CDCl}_{3}$ ): $\delta$ 7.24-7.28 (m, 2H), 7.147.19 (m, 3H), 6.29 (br. s, $1 \mathrm{H}), 3.47$ (dd, $J=9.2,4.0 \mathrm{~Hz}, 1 \mathrm{H}), 2.93-2.99$ (m, 1H), 2.57-2.71 (m, 2H), 2.43-2.49 (m, 1H), 2.30 (br. s, 1H), 1.70$1.95(\mathrm{~m}, 8 \mathrm{H}), 1.11-1.39(\mathrm{~m}, 4 \mathrm{H}) ;{ }^{13} \mathrm{C} \mathrm{NMR}\left(100 \mathrm{MHz}, \mathrm{CDCl}_{3}\right): \delta 173.3$, 142.3, 128.5 (2C overlapped), 128.4 (2C overlapped), 125.8, 58.9, 58.1, 53.3, 35.8, 32.6, 31.6, 30.9, 28.7, 25.0, 23.8; HRMS (ESI-TOF) calcd for $\mathrm{C}_{17} \mathrm{H}_{24} \mathrm{~N}_{2} \mathrm{O}[\mathrm{M}+\mathrm{H}]^{+} m / z: 273.1967$, found: 273.1971 .

4-(3-Phenylpropyl)-(1R,4S,6R)-3-oxo-2,5-diazabicyclo[4.4.0] decane $\left(\mathbf{5} \mathbf{c}^{\prime}\right)$. Using general procedure C; colorless solid; $95 \mathrm{mg}$; 
yield $=35 \%$; mp $58-60{ }^{\circ} \mathrm{C} ;[\alpha]_{\mathrm{D}}^{20}-15\left(c 0.48, \mathrm{CH}_{2} \mathrm{Cl}_{2}\right)$; IR $(\mathrm{KBr})$ : 696, 1352, 1409, 1453, 1496, 1659, 2854, 2934, 3026, 3061, 3190, $3269 \mathrm{~cm}^{-1} ;{ }^{1} \mathrm{H}$ NMR (400 MHz, $\left.\mathrm{CDCl}_{3}\right): \delta 7.25(\mathrm{t}, J=7.0 \mathrm{~Hz}, 2 \mathrm{H})$, 7.13-7.17 (m, 3H), 6.25 (br. s, 1H), 3.52-3.55 (m, 1H), 2.93-3.00 $(\mathrm{m}, 1 \mathrm{H}), 2.63(\mathrm{t}, J=7.3 \mathrm{~Hz}, 2 \mathrm{H}), 2.43-2.49(\mathrm{~m}, 1 \mathrm{H}), 2.00-2.05(\mathrm{~m}$, 1H), 1.69-1.81 (m, 8H), 1.21-1.36 (m, 4H); ${ }^{13} \mathrm{C}$ NMR (100 MHz, $\mathrm{CDCl}_{3}$ ): $\delta 172.3,142.4,128.5$ (2C overlapped), 128.4 (2C overlapped), 125.8, 59.5, 58.4, 58.2, 36.1, 32.4, 31.5, 30.8, 28.1, 24.8, 23.9; HRMS (ESI-TOF) calcd for $\mathrm{C}_{17} \mathrm{H}_{24} \mathrm{~N}_{2} \mathrm{O}[\mathrm{M}+\mathrm{H}]^{+} \mathrm{m} / \mathrm{z}$ : 273.1967, found: 273.1971 .

\section{4-(3,7-Dimethyloct-6-en-1-yl)-(1R,4S,6R)-3-oxo-2,5-}

diazabicyclo[4.4.0]decane (5d). Using general procedure $C$; colorless solid; $120 \mathrm{mg}$; yield $=41 \%$; mixture of epimers 1 : 1 ; IR (KBr): 812, 844, 1126, 1352, 1363, 1451, 1659, 2858, 2936, 3177, 3299, $3426 \mathrm{~cm}^{-1}$; ${ }^{1} \mathrm{H} \mathrm{NMR}\left(400 \mathrm{MHz}, \mathrm{CDCl}_{3}\right.$, both isomers present): $\delta 6.03$ (br. s, $2 \mathrm{H}), 5.05-5.10(\mathrm{~m}, 2 \mathrm{H}), 3.42$ (ddd, $J=10.0$, $3.7,2.8 \mathrm{~Hz}, 2 \mathrm{H}), 2.96-3.02(\mathrm{~m}, 2 \mathrm{H}), 2.49-2.56$ (m, 2H), 1.41-2.03 $(\mathrm{m}, 18 \mathrm{H}), 1.66(\mathrm{~s}, 6 \mathrm{H}), 1.58(\mathrm{~s}, 6 \mathrm{H}), 1.09-1.54(\mathrm{~m}, 18 \mathrm{H}), 0.88$ (d, $J$ $=6.4 \mathrm{~Hz}, 3 \mathrm{H}), 0.878(\mathrm{~d}, J=6.4 \mathrm{~Hz}, 3 \mathrm{H}) ;{ }^{13} \mathrm{C}$ NMR $(100 \mathrm{MHz}$, $\mathrm{CDCl}_{3}$, both isomers present): $\delta 173.3,173.27,131.2$ (2C overlapped), 125.0, 124.9, 58.8, 58.77, 58.6 (2C overlapped), 53.3, 53.27, 37.2, 36.9, 34.2, 33.9, 32.6, 32.3, 31.6 (2C overlapped), 30.9 (2C overlapped), 30.5, 30.1, 25.8 (2C overlapped), 25.7, 25.5, 24.9 (2C overlapped), 23.8 (2C overlapped), 19.7, 19.5, 17.7 (2C overlapped); HRMS (ESI-TOF) calcd for $\mathrm{C}_{18} \mathrm{H}_{33} \mathrm{~N}_{2} \mathrm{O}[\mathrm{M}+\mathrm{H}]^{+} \mathrm{m} / z$ : 293.2593, found: 293.2603 .

4-(3,7-Dimethyloct-6-en-1-yl)-(1R,4S,6R)-3-oxo-2,5-

diazabicyclo[4.4.0]decane $\left(\mathbf{5 d}^{\prime}\right)$. Using general procedure $\mathrm{C}$; colorless solid; $58 \mathrm{mg}$; yield $=20 \%$; mixture of epimers 1 : 1 ; IR (KBr): 831, 1121, 1350, 1452, 1664, 2858, 2928, 3258, $3428 \mathrm{~cm}^{-1}$; ${ }^{1} \mathrm{H} \mathrm{NMR} \mathrm{(400} \mathrm{MHz,} \mathrm{CDCl}_{3}$, both isomers present): $\delta 6.08$ (br. s, 2H), 5.04-5.08 (m, 2H), 3.49 (dd, $J=8.3,3.4 \mathrm{~Hz}, 2 \mathrm{H}), 2.99-3.03$ (m, 2H), 2.46-2.52 (m, 2H), 1.52-2.02 (m, 18H), $1.65(\mathrm{~s}, 6 \mathrm{H}), 1.57$ (s, 6H), 1.09-1.48 (m, 18H), 0.88 (d, $J=6.4 \mathrm{~Hz}, 3 \mathrm{H}), 0.87$ (d, $J=$ $6.4 \mathrm{~Hz}, 3 \mathrm{H}) ;{ }^{13} \mathrm{C}$ NMR (100 $\mathrm{MHz}, \mathrm{CDCl}_{3}$, both isomers present): $\delta 171.8,171.7,131.21,131.2,124.93,124.9,59.8$ (2C overlapped), 58.5 (2C overlapped), 57.8 (2C overlapped), 37.2, 36.9, 33.1, 33.0, 32.72, 32.7, 31.6 (2C overlapped), 30.4 (2C overlapped), 29.9 (2C overlapped), 25.8 (2C overlapped), 25.6 (2C overlapped), 24.7 (2C overlapped), 23.8 (2C overlapped), 19.6, 19.5, 17.8 (2C overlapped); HRMS (ESI-TOF) calcd for $\mathrm{C}_{19} \mathrm{H}_{33} \mathrm{~N}_{2} \mathrm{O}[\mathrm{M}+\mathrm{H}]^{+} \mathrm{m} / \mathrm{z}$ : 293.2593, found: 293.2603.

4-(((1R,3S,4R)-2-((S)-1-Phenylethyl)-2-azabicyclo[2.2.1]heptan-3-yl)methyl)-(1R,4R,6R)-3-oxo-2,5-diazabicyclo[4.4.0]decane (5e). Using general procedure C; colorless oil; $115 \mathrm{mg}$; yield = 43\%; IR (KBr): 702, 763, 1128, 1360, 1451, 1627, 1683, 2860, 2936, 3062, $3205 \mathrm{~cm}^{-1} ;{ }^{1} \mathrm{H}$ NMR (400 MHz, $\left.\mathrm{CDCl}_{3}\right): \delta 7.19-7.33$ (m, 5H), 5.93 (br. s, $1 \mathrm{H}), 3.79$ (q, $J=6.4 \mathrm{~Hz}, 1 \mathrm{H}), 2.96-3.11(\mathrm{~m}$, $2 \mathrm{H}), 2.82-2.90(\mathrm{~m}, 1 \mathrm{H}), 2.47-2.62(\mathrm{~m}, 2 \mathrm{H}), 2.26-2.33(\mathrm{~m}, 1 \mathrm{H})$, 2.09-2.16 (m, 1H), 1.59 (q, $J=8.0 \mathrm{~Hz}, 2 \mathrm{H}), 1.31(\mathrm{~d}, J=6.7 \mathrm{~Hz}$, $3 \mathrm{H}), 1.21-1.89(\mathrm{~m}, 13 \mathrm{H}), 0.86-0.94(\mathrm{~m}, 1 \mathrm{H}) ;{ }^{13} \mathrm{C}$ NMR $(100 \mathrm{MHz}$, $\mathrm{CDCl}_{3}$ ): $\delta$ 166.0, 158.7, 146.0, 128.4 (2C overlapped), 126.9, 126.7 (2C overlapped), 62.5, 57.0, 56.7, 54.4, 40.8, 38.6, 33.4, 32.9, 32.8, 31.9, 31.1, 30.1, 25.3, 24.8, 23.8; HRMS (ESI-TOF) calcd for $\mathrm{C}_{23} \mathrm{H}_{34} \mathrm{~N}_{3} \mathrm{O}[\mathrm{M}+\mathrm{H}]^{+} \mathrm{m} / z: 368.2702$, found: 368.2704.

4-(Neopentyl)-(1R,6R)-3-thio-2,5-diazabicyclo[4.4.0]dec-4-ene (6b). Using procedure D; yellow solid; $81 \mathrm{mg}$; yield $=34 \%$; $\mathrm{mp}$
104-105 ${ }^{\circ} \mathrm{C} ;[\alpha]_{\mathrm{D}}^{20}-147\left(c 0.30, \mathrm{CH}_{2} \mathrm{Cl}_{2}\right.$ ); IR (KBr): 1039, 1179, 1314, 1359, 1449, 1520, 1604, 1674, 2862, 2937, $3159 \mathrm{~cm}^{-1} ;{ }^{1} \mathrm{H}$ NMR (400 MHz, $\mathrm{CDCl}_{3}$ ): $\delta 8.48$ (br. s, $1 \mathrm{H}$ ), 3.74 (dd, $J=12.4$, $1.8 \mathrm{~Hz}, 1 \mathrm{H}), 2.97-3.01$ (m, 1H), 2.79-2.87 (m, 1H), 2.38-2.40 (m, $1 \mathrm{H}), 2.15(\mathrm{~d}, J=12.5 \mathrm{~Hz}, 1 \mathrm{H}), 2.02-2.06(\mathrm{~m}, 1 \mathrm{H}), 1.80-1.87(\mathrm{~m}$, 2H), 1.29-1.47 (m, 4H), 0.94 (s, 9H); $\left.{ }^{13} \mathrm{C} \mathrm{NMR} \mathrm{(100} \mathrm{MHz,} \mathrm{CDCl}_{3}\right)$ : $\delta$ 187.0, 164.3, 62.2, 55.6, 46.7, 32.03, 32.01, 30.0, 29.9 (3C overlapped), 25.0, 24.0; HRMS (ESI-TOF) calcd for $\mathrm{C}_{13} \mathrm{H}_{22} \mathrm{~N}_{2} \mathrm{~S}$ [M $+\mathrm{H}]^{+} \mathrm{m} / \mathrm{z}: 239.1582$, found: 239.1595 .

4-Neopentyl-(1R,4S,6R)-3-thio-2,5-diazabicyclo[4.4.0]decane (6c). Using general procedure C; colorless solid; $122 \mathrm{mg}$; yield = 51\%; mp 180-182 ${ }^{\circ} \mathrm{C} ;[\alpha]_{\mathrm{D}}^{20}-89$ (c 0.12, $\left.1 \mathrm{M} \mathrm{HCl}\right)$; IR (KBr): 1035, 1056, 1288, 1340, 1359, 1541, 2861, 2952, 3153, 3260, $3436 \mathrm{~cm}^{-1}$; ${ }^{1} \mathrm{H}$ NMR (400 MHz, $\left.\mathrm{CDCl}_{3}\right): \delta 8.38$ (br. s, $\left.1 \mathrm{H}\right), 3.77$ (d, $J=8.6 \mathrm{~Hz}, 1 \mathrm{H}), 2.91-2.95(\mathrm{~m}, 1 \mathrm{H}), 2.79(\mathrm{dd}, J=14.4,1.8 \mathrm{~Hz}, 1 \mathrm{H})$, 2.47-2.53 (m, 1H), 1.77-1.87 (m, 4H), 1.39 (dd, $J=14.4,8.6 \mathrm{~Hz}$, 1H), 1.14-1.41 (m, 5H), 1.00 (s, 9H); $\left.{ }^{13} \mathrm{C} \mathrm{NMR} \mathrm{(100} \mathrm{MHz,} \mathrm{CDCl}_{3}\right)$ : $\delta$ 206.9, 63.4, 60.7, 57.5, 50.6, 31.2, 30.9, 30.8, 30.2 (3C overlapped), 24.7, 24.1; HRMS (ESI-TOF) calcd for $\mathrm{C}_{13} \mathrm{H}_{25} \mathrm{~N}_{2} \mathrm{~S}[\mathrm{M}+$ $\mathrm{H}]^{+} m / z: 241.1738$, found: 241.1731 .

4-Neopentyl-(1R,4R,6R)-3-thio-2,5-diazabicyclo[4.4.0]decane $\left(6 \mathbf{c}^{\prime}\right)$. Using general procedure $\mathrm{C}$; colorless solid; $58 \mathrm{mg}$; yield = 24\%; mp 175-177 ${ }^{\circ} \mathrm{C} ;[\alpha]_{\mathrm{D}}^{20}+37$ (c 0.11, $\left.1 \mathrm{M} \mathrm{HCl}\right)$; IR (KBr): 1032, 1061, 1353, 1365, 1543, 2855, 2929, 2950, 3143, 3263, $3436 \mathrm{~cm}^{-1}$; ${ }^{1} \mathrm{H}$ NMR (400 MHz, $\mathrm{CDCl}_{3}$ ): $\delta 8.17$ (br. s, $1 \mathrm{H}$ ), 3.99 (dd, $J=9.3,1.8 \mathrm{~Hz}, 1 \mathrm{H}), 2.89-2.92(\mathrm{~m}, 1 \mathrm{H}), 2.55-2.61(\mathrm{~m}, 1 \mathrm{H})$, $2.16(\mathrm{dd}, J=14.2,1.8 \mathrm{~Hz}, 1 \mathrm{H}), 1.79-1.86(\mathrm{~m}, 4 \mathrm{H}), 1.64(\mathrm{dd}, J=$ 14.4, $9.5 \mathrm{~Hz}, 1 \mathrm{H}), 1.54$ (br. s, 1H), 1.15-1.42 (m, 4H), 1.01 (s, 9H); ${ }^{13} \mathrm{C} \mathrm{NMR}\left(100 \mathrm{MHz}, \mathrm{CDCl}_{3}\right): \delta 207.6,62.4,61.1,51.5,48.9,31.4$, 31.0, 30.9, 30.0 (3C overlapped), 25.0, 24.2; HRMS (ESI-TOF) calcd for $\mathrm{C}_{13} \mathrm{H}_{25} \mathrm{~N}_{2} \mathrm{~S}[\mathrm{M}+\mathrm{H}]^{+} \mathrm{m} / z$ : 241.1738, found: 241.1731 .

Dimethyl-[4-neopentyl-(1R,4R,6R)-3-oxo-2,5-diazabicyclo[4.4.0] dec-4-yl]-phosphonate (6d). Using procedure E; colorless solid; 308 mg; yield = 87\%; mp 103-105 ${ }^{\circ} \mathrm{C} ;[\alpha]_{\mathrm{D}}^{20}+37\left(c 0.35, \mathrm{CH}_{2} \mathrm{Cl}_{2}\right)$; IR (KBr): 1028, 1059, 1243, 1342, 1463, 1670, 2860, 2952, 3225, $3436 \mathrm{~cm}^{-1}$; ${ }^{1} \mathrm{H}$ NMR (400 MHz, $\mathrm{CDCl}_{3}$ ): $\delta 5.95$ (br. s, $\left.1 \mathrm{H}\right), 3.79(\mathrm{~d}, J$ $=10.4 \mathrm{~Hz}, 6 \mathrm{H}), 3.05-3.07(\mathrm{~m}, 2 \mathrm{H}), 2.36(\mathrm{dd}, J=14.4,3.1 \mathrm{~Hz}, 1 \mathrm{H})$, 1.70-1.79 (m, 5H), 1.59 (dd, $J=14.4,12.2 \mathrm{~Hz}, 1 \mathrm{H}), 1.15-1.41$ (m, $4 \mathrm{H}), 1.00(\mathrm{~s}, 9 \mathrm{H}) ;{ }^{13} \mathrm{C} \mathrm{NMR}\left(100 \mathrm{MHz}, \mathrm{CDCl}_{3}\right): \delta 169.4,66.9(\mathrm{~d}, J=$ $120.7 \mathrm{~Hz}), 57.5,55.0,54.0,53.9,53.8,44.9,32.2$ (d, $J=15.0 \mathrm{~Hz})$, 31.2 (3C overlapped), 30.7 (d, $J=13.2 \mathrm{~Hz}$ ), 24.2, 23.9; ${ }^{31} \mathrm{P}\left\{{ }^{1} \mathrm{H}\right\} \mathrm{NMR}$ $\left(162 \mathrm{MHz}, \mathrm{CDCl}_{3}\right.$ ): $\delta$ 27.2; HRMS (ESI-TOF) calcd for $\mathrm{C}_{15} \mathrm{H}_{29} \mathrm{~N}_{2} \mathrm{O}_{4^{-}}$ $\mathrm{PNa}[\mathrm{M}+\mathrm{Na}]^{+} \mathrm{m} / z: 355.1763$, found: 355.1771.

[4-Neopentyl-(1R,4R,6R)-3-oxo-2,5-diazabicyclo[4.4.0]dec-4yl]-phosphonic acid (6e). Using procedure E; colorless solid; 217 mg; yield = 72\%; dr = 93 : 7; IR (KBr): 557, 1081, 1207, 1261, 1345, 1470, 1601, 1651, 2949, 3051, $3180 \mathrm{~cm}^{-1} ;{ }^{1} \mathrm{H}$ NMR (400 $\left.\mathrm{MHz}, \mathrm{CDCl}_{3}\right): \delta 3.77-3.82(\mathrm{~m}, 1 \mathrm{H}), 3.54-3.57(\mathrm{~m}, 1 \mathrm{H}), 3.20(\mathrm{~s}$, $2 \mathrm{H}), 2.56$ (dd, $J=15.9,4.6 \mathrm{~Hz}, 1 \mathrm{H}), 1.51-2.05(\mathrm{~m}, 5 \mathrm{H}), 1.16-1.30$ $(\mathrm{m}, 2 \mathrm{H}), 0.92(\mathrm{~s}, 9 \mathrm{H}) ;{ }^{13} \mathrm{C} \mathrm{NMR}\left(100 \mathrm{MHz}, \mathrm{CDCl}_{3}\right): \delta 167.9,67.8$ (d, $J=120.0 \mathrm{~Hz}$ ), 57.0, 53.1, 48.9, 43.5, 30.3 (3C overlapped), 30.2, 26.8, 23.6, 22.4; ${ }^{31} \mathrm{P}\left\{{ }^{1} \mathrm{H}\right\}$ NMR (162 $\mathrm{MHz}, \mathrm{CDCl}_{3}$ ): $\delta$ 9.9; HRMS (ESI-TOF) calcd for $\mathrm{C}_{13} \mathrm{H}_{26} \mathrm{~N}_{2} \mathrm{O}_{4} \mathrm{P}[\mathrm{M}+\mathrm{H}]^{+} \mathrm{m} / z: 303.1474$, found: 303.1476.

4-Neopentyl-(1R,4S,6R)-2,5-diazabicyclo[4.4.0]decane (6f). Using procedure F; colorless solid; $70 \mathrm{mg}$; yield $=67 \%$; $\mathrm{mp} 42-$ $44^{\circ} \mathrm{C} ;[\alpha]_{\mathrm{D}}^{20}+24\left(c 0.17, \mathrm{CH}_{2} \mathrm{Cl}_{2}\right)$; IR (KBr): 833, 1113, 1325, 1366, 
1450, 1466, 1650, 2854, 2927, 3273, $3413 \mathrm{~cm}^{-1} ;{ }^{1} \mathrm{H}$ NMR (400 $\left.\mathrm{MHz}, \mathrm{CDCl}_{3}\right): \delta 2.92(\mathrm{dd}, J=11.6,3.1 \mathrm{~Hz}, 1 \mathrm{H}), 2.77-2.82(\mathrm{~m}, 1 \mathrm{H})$, 2.49 (dd, $J=11.6,10.4 \mathrm{~Hz}, 1 \mathrm{H}), 2.25-2.31(\mathrm{~m}, 1 \mathrm{H}), 2.16-2.21(\mathrm{~m}$, 1H), 1.58-1.71 (m, 4H), 1.56 (br. s, 2H), 1.14-1.33 (m, 6H), 0.91 $(\mathrm{s}, 9 \mathrm{H}) ;{ }^{13} \mathrm{C}$ NMR $\left(100 \mathrm{MHz}, \mathrm{CDCl}_{3}\right): \delta$ 61.9, 60.5, 54.27, 54.25, 48.8, 32.3, 32.0, 30.5, 30.1 (3C overlapped), 25.1, 24.9; HRMS (ESI-TOF) calcd for $\mathrm{C}_{13} \mathrm{H}_{27} \mathrm{~N}_{2}[\mathrm{M}+\mathrm{H}]^{+} \mathrm{m} / z: 211.2174$, found: 211.2169.

\section{ECD measurement}

ECD spectra were carried out using a Jasco J-815 spectrometer (Tokyo, Japan) at room temperature in spectroscopic grade $\mathrm{CH}_{3} \mathrm{CN}\left(6.0 \times 10^{-4} \mathrm{M}\right)$ in quartz cells with a path length $0.1,0.2$ or $1 \mathrm{~cm}$. All spectra were measured using a scanning speed of $100 \mathrm{~nm} \mathrm{~min}{ }^{-1}$, a step size of $0.2 \mathrm{~nm}$, a bandwidth of $1 \mathrm{~nm}$, a response time of 0.5 seconds, and an accumulation of 5 scans. The spectra were background-corrected using solvent recorded under the same conditions.

\section{Conformational search and simulations of ECD spectra}

The conformational search was carried out using CONFLEX 7 software ${ }^{13}$ with the MMFF94s force fields within $10 \mathrm{kcal} \mathrm{mol}^{-1}$ energy window. Next, all the obtained structures were submitted to the Gaussian16 (version C.01) program for DFT reoptimisation at the B97XD/6-311+G(d,p) using PCM model for $\mathrm{CH}_{3} \mathrm{CN}$. All conformers were confirmed to contain no imaginary frequencies. The final structures within $1.5 \mathrm{kcal} \mathrm{mol}^{-1}$ energy window were selected for subsequent simulations of ECD spectra. Boltzmann populations were calculated at $298 \mathrm{~K}$. Theoretical ECD/UV spectra were simulated at the CAM-B3LYP/ def2-TZVP level using the PCM model for $\mathrm{CH}_{3} \mathrm{CN}$. Furthermore, the ECD spectra were calculated using aug-cc-pVDZ basis set with B3LYP functional; the obtained results are similar to CAMB3LYP/def2-TZVP. Calculations were performed for the first 50 excited electronic states. Rotatory strengths were calculated using both the length and the velocity formalisms. The differences between these two were less than $5 \%$, so only the velocity representations $\left(R_{\mathrm{vel}}\right)$ were taken into account. The UV correction was applied according the experimental data recorder under the same conditions as mentioned beforehand.

\section{Conflicts of interest}

There are no conflicts to declare.

\section{Acknowledgements}

M. G. thanks the Wroclaw Centre for Networking and Supercomputing (WCSS) for the computational support.

\section{Notes and references}

1 (a) J. Iwanejko and E. Wojaczyńska, Org. Biomol. Chem., 2018, 16, 7296-7314; (b) E. Speich, L. Banfi, L. Moni, R. Riva, V. Rocca and A. Basso, Chem. Heterocycl. Compd., 2018, 54,
329-333; (c) P. Capurro, L. Moni, A. Galatini, C. Mang and A. Basso, Molecules, 2018, 23, 2758-2763.

2 Z. Zhang, W. Zhang, F. Kang, F. C. F. Ip, N. Y. Ip and R. Tong, J. Org. Chem., 2019, 84, 11359-11365.

3 C. Y. Wu and M. H. Xu, Org. Lett., 2019, 21, 5035-5039.

4 P. Zheng, S. Wu, C. Mou, W. Xue, Z. Jin and Y. R. Chi, Org. Lett., 2019, 21, 5026-5029.

5 J. Pan, J. H. Wu, H. Zhang, X. Ren, J. P. Tan, L. Zhu, H. S. Zhang, C. Jiang and T. Wang, Angew. Chem., Int. Ed., 2019, 58, 7425-7430.

6 (a) O. I. El-Sabbagh, M. E. El-Sadek, S. M. Lashine, S. H. Yassin and S. M. El-Nabtity, Med. Chem. Res., 2009, 18, 782-797; (b) J. Iwanejko, E. Wojaczyńska, J. Trynda, M. Maciejewska, J. Wietrzyk, A. Kochel and J. Wojaczyński, Tetrahedron, 2017, 73, 2276-2282.

7 (a) R. Liu, Z. Huang, M. G. Murray, X. Guo and G. Liu, J. Med. Chem., 2011, 54, 5747-5768; (b) X. Xie, Y. Yan, N. Zhu and G. Liu, Eur. J. Med. Chem., 2014, 76, 67-78; (c) L. Shi, H. Zhou, J. Wu and X. Li, Mini-Rev. Org. Chem., 2015, 12, 96-112; (d) S. Tariq, K. Somakala and M. Amir, Eur. J. Med. Chem., 2018, 143, 542-557; (e) Y. Ramli, A. Moussaif, K. Karrouchi and E. M. Essassi, J. Chem., 2014, 563406.

8 (a) S. N. Murthy, B. Madhav and Y. V. D. Nageswar, Helv. Chim. Acta, 2010, 93, 1216-1220; (b) M. Periasamy, B. Venkanna, M. Nagaraju and L. Mohan, Synthesis, 2020, 52, 127-134; (c) S. Gräßle, S. Vanderheiden, P. Hodapp, B. Bulat, M. Nieger, N. Jung and S. Bräse, Org. Lett., 2016, 18, 3598-3601; (d) L. Damas, R. M. B. Carrilho, S. C. C. Nunes, A. A. C. C. Pais, L. Kollár, M. Pineiro and M. M. Pereira, R. Soc. Open Sci., 2018, 5, 181140.

9 (a) E. Wojaczyńska, J. Wojaczyński, K. Kleniewska, M. Dorsz and T. K. Olszewski, Org. Biomol. Chem., 2015, 13, 6116-6148; (b) T. K. Olszewski, E. Wojaczyńska, R. Wieczorek and J. Bąkowicz, Tetrahedron: Asymmetry, 2015, 26, 601-607; (c) T. K. Olszewski, Tetrahedron: Asymmetry, 2015, 26, 393-399; (d) E. Pięta, E. Podstawka-Proniewicz, B. Boduszek, T. K. Olszewski, M. Nattich-Rak and Y. Kim, Appl. Surf. Sci., 2015, 335, 167-183; (e) E. Podstawka-Proniewicz, E. Pięta, K. Zborowski, A. Kudelski, B. Boduszek, T. K. Olszewski, Y. Kim and L. M. Proniewicz, J. Phys. Chem. A, 2014, 118, 5614-5625; (f) P. Knapkiewicz, K. Skowerski, D. E. Jaskolska, M. Barbasiewicz and T. K. Olszewski, Org. Process Res. Dev., 2012, 16, 1430-1435; (g) T. K. Olszewski and D. E. Jaskólska, Heteroat. Chem., 2012, 23, 605-609; $(h)$ A. Bulow, T. Meyer, T. K. Olszewski and M. Bols, Eur. J. Org. Chem., 2004, 323-329.

10 (a) J. Iwanejko, A. Brol, B. Szyja, M. Daszkiewicz, E. Wojaczyńska and T. K. Olszewski, Tetrahedron, 2019, 75, 1431-1439; (b) J. Iwanejko, A. Brol, B. Szyja, M. Daszkiewicz, E. Wojaczyńska and T. K. Olszewski, Org. Biomol. Chem., 2019, 17, 7352-7359.

11 The Horner-Wadsworth-Emmons (HWE) reaction is widely used in organic synthesis among existing methodologies as one of the most reliable methods for the highly stereoselective olefination of carbonyl compounds with a broad substrate scope. Kobayashi et al. in a review described recent applications of the HWE reaction in 
natural product synthesis, highlighting its use for carbon chain elongation, coupling reactions of synthetic segments, ring-closing reactions, tandem reactions including HWE olefination, and asymmetric reactions: K. Kobayashi, K. Tanaka III and H. Kogen, Tetrahedron Lett., 2018, 59, 568-582.

12 (a) M. Woźnica, P. Kowalska, M. Łysek, M. Masnyk, M. Górecki, M. Kwit, F. Furche and J. Frelek, Curr. Org. Chem., 2010, 14, 1022-1036; (b) R. Kołodziejska, M. Górecki, J. Frelek and M. Dramiński, Tetrahedron:
Asymmetry, 2012, 23, 683-689; (c) S. Qiu, E. De Gussem, K. Abbaspour Tehrani, S. Sergeyev, P. Bultinck and W. Herrebout, J. Med. Chem., 2013, 56, 8903-8914; (d) G. Pescitelli and T. Bruhn, Chirality, 2016, 28, 466-474; (e) N. U. Rehman, H. Hussain, S. Al-Shidhani, S. K. Avula, G. Abbas, M. U. Anwar, M. Górecki, G. Pescitelli and A. AlHarrasi, RSC Adv., 2017, 7, 42357-42362.

13 (a) H. Goto and E. Osawa, J. Am. Chem. Soc., 1989, 111, 89508951; (b) H. Goto and E. Osawa, J. Chem. Soc., Perkin Trans. 2, 1993, 187-198. 